\title{
A Study on the Impact of Covid-19 on Students Learning Experiences with Special Reference to Madurai City
}

\section{OPEN ACCESS}

Manuscript ID:

COM-2021-09013471

Volume: 9

Issue: 1

Month: January

Year: 2021

E-ISSN: 2582-6190

Received: 14.10 .2020

Accepted: 28.11.2020

Published: 01.01.2021

Citation:

Margaret Divya, A., and Suganthi Priya. "A Study on the Impact of Covid-19 on Students Learning Experiences with Special Reference to Madurai City." ComFin Research, vol. 9, no. 1, 2021, pp. 11-16.

DOI:

https://doi.org/10.34293/ commerce.v9i1.3471

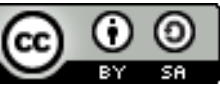

This work is licensed under a Creative Commons Attribution-ShareAlike 4.0 International License

\author{
A. Margaret Divya \\ Assistant Professor, Department of Commerce, Lady Doak College, Madurai, Tamil Nadu, India \\ https://orcid.org/0000-0001-9675-9238
}

\author{
Suganthi Priya \\ Department of Commerce, Lady Doak College, Madurai, Tamil Nadu, India
}

\begin{abstract}
Corona viruses are a large family of viruses, causing less severe common cold to more severe diseases such as severe acute respiratory syndrome (SARS) and the Middle East respiratory syndrome (MERS). The SARS-CoV-21 is a corona virus very similar to the one that caused SARS. There is evidence that the SARS-CoV-2 has also been transmitted from bats. Like other corona viruses, SARS-CoV-2 virus particles are spherical and have mushroom-shaped proteins called spikes protruding from their surface, giving the particles a crown-like appearance. The spike binds and fuses to human cells, allowing the virus to gain entry. Researchers at the University of Texas at Austin and the National Institutes of Health, U.S., have produced a 3D atomic-scale map of the protein of the SARS-CoV-2 that binds to and infects human cells. Mapping the $3 D$ structure of the protein - spike (S) glycoprotein - will allow a better understanding of how the virus binds to the human cells. Knowing the structure of the spike protein will, in turn, allow scientists to develop vaccines and antivirals against the virus and even better diagnostics. The World Health Organisation has declared COVID-19 to be a pandemic4. The symptoms of COVID-19 appear within two to 14 days after exposure and include fever, cough, a runny nose and difficulty in breathing. This paper provides a comprehensive review of the COVID-19 and how this great pandemic has bothered the ordinary life of every citizen, with more focus on the economic imbalance created in India. This study has also attempted to know the students learning experiences and their attitude due to this lockdown period amidst the demanding end of the semester requirements in the year 2020. It also attempts to know their expectations, anxieties, plans and problems encountered by them about COVID-19 by being at home, having in mind their career development.
\end{abstract}

Keywords: Asymptomatic, COVID-19, Case fatality rate (CFR), Community transmission / spread, Cordon sanitaire, Contact tracing

\section{Introduction}

Corona virus disease (COVID-19) is an infectious disease caused by a newly discovered corona virus. Most people infected with the COVID-19 virus will experience mild to moderate respiratory illness and recover without requiring special treatment. Older people and those with underlying medical problems like cardiovascular disease, diabetes, chronic respiratory disease, and cancer are more likely to develop serious illness. The best way to prevent and slow down transmission is to be well informed about the COVID-19 virus, the disease it causes and how it spreads. The COVID-19 virus spreads primarily through droplets of saliva or discharge from the nose when an infected person coughs or sneezes. At this time, there are no specific vaccines or treatments for COVID-19. However, there are many ongoing clinical trials evaluating potential treatments. World Health Organisation (WHO) will continue to provide updated information as soon as clinical findings become available. The virus can be detected using a PCR test. 


\section{Statement of the Problem}

Crises tend to bring out both the best and the worst in people. On the one hand, the COVID-19 pandemic has people picking up groceries for their elderly neighbors, sewing masks, and sending hand sanitizer to those in need. Simultaneously, others are hoarding toilet paper, spreading conspiracy theories on social media, and failing to follow health directives from authorities. Hardly anyone is going through the normal routine of getting ready for work, commuting to the office, spending the day with colleagues, returning home, and enjoying the evening with family and friends. As the current scenario is such that the researcher(s) being in the field of education are interested to know about the student's mentality about this Covid-19. This fact kindled the interest in the researchers to undertake the present study.

\section{Objectives}

1. To learn the facts about the current pandemic Covid-19.

2. To know the student's opinion towards Covid-19 and online learning.

3. To analyze the students' attitude towards a future career, problems faced and measures/remedies available due to this pandemic.

\section{Methodology}

The present study comprises both primary and secondary data collected from the students, including schools and colleges in and around Madurai city.

Primary Data: The primary data were collected from various respondents, including schools and colleges situated in Madurai city.

Secondary Data: The secondary data were also collected from various standard text books, magazines, journals, newspapers and the internet, which constituted supportive literature to make analysis and suggestions.

Period of the Study: The study was undertaken in the year 2020 during the Covid-19 Lockdown during March, April \& May 2020.
Sampling Design: A convenience sampling technique was used.

Sample Size: A sample size of 275 respondents was selected for this study.

Statistical Analysis: Simple techniques such as percentage, mean, Garret Ranking and Likert scaling of the scores regarding the student's opinion towards Covid-19 and their attitude regarding future career, problems faced and measures/remedies available due to this pandemic is being analyzed by the use of appropriate statistical techniques.

\section{Analysis and Interpretation}

Table 1: Demographic Profile of Respondents

\begin{tabular}{|l|c|}
\hline Gender & Percentage \\
\hline Male & 13.1 \\
\hline Female Total & 86.9 \\
\hline \multicolumn{2}{|c|}{ Tot } \\
\hline
\end{tabular}

Interpretation: $13.1 \%$ of the respondents are male and $86.9 \%$ of the respondents are female

\begin{tabular}{|l|c|}
\hline \multicolumn{1}{|c|}{ Residential status } & Percentage \\
\hline Urban & 72 \\
\hline Semi-urban & 12 \\
\hline Rural $\quad$ Total & 16 \\
\hline \multicolumn{2}{c|}{100} \\
\hline
\end{tabular}

Interpretation: $72 \%$ of the respondents are residing in urban area, respondents residing in semi-urban area is $12 \%$ and $16 \%$ of the respondents are residing in rural area

\begin{tabular}{|c|c|}
\hline Educational Qualification & Percentage \\
\hline SSLC & 4.7 \\
\hline HSC & 17.8 \\
\hline Diploma & 0.4 \\
\hline UG & 67.3 \\
\hline PG & 9.8 \\
\hline Total & 100 \\
\hline \multicolumn{2}{|c|}{$\begin{array}{l}\text { Interpretation: } 4.7 \% \text { of the respondents are studying } \\
\text { class } 10,17.8 \% \text { of the respondents are class } 12 \\
\text { students, } .4 \% \text { of the respondents are Diploma holders, } \\
67.3 \% \text { of the respondents are Under graduates and } 9.8 \\
\text { of the respondents are Post graduates }\end{array}$} \\
\hline
\end{tabular}

Source: Primary Data 
Table 2: Opinion Towards Covid-19 and Online Learning

\begin{tabular}{|c|c|}
\hline Studying in Home Country & Percentage \\
\hline Yes & 92.7 \\
\hline No & 7.3 \\
\hline Total & 100 \\
\hline
\end{tabular}

Interpretation: $92.7 \%$ of the respondents are studying in home country and $7.3 \%$ of the respondents are studying in abroad.

\begin{tabular}{|c|c|}
\hline Aware of Virus Outbreak & Percentage \\
\hline Yes & 97.5 \\
\hline No & 2.5 \\
\hline Total & 100 \\
\hline
\end{tabular}

Interpretation: $97.5 \%$ of the respondents are aware of this virus outbreak.

\begin{tabular}{|c|c|}
\hline Update covid-19 & Percentage \\
\hline Yes & 93.1 \\
\hline No & 6.9 \\
\hline Total & 100 \\
\hline
\end{tabular}

Interpretation: $93.1 \%$ of the respondents update their self of this virus outbreak on daily basis

\begin{tabular}{|c|c|}
\hline Financial Crisis & Percentage \\
\hline Yes & 61.8 \\
\hline No & 38.2 \\
\hline Total & 100 \\
\hline
\end{tabular}

Interpretation: $61.8 \%$ of the respondents are facing financial crisis due to covid-19

\begin{tabular}{|l|c|}
\hline \multicolumn{1}{|c|}{ If yes-(extend) } & Percentage \\
\hline Bad & 2.5 \\
\hline Worst & 2.9 \\
\hline Tough & 9.8 \\
\hline Manageable & 38.5 \\
\hline No idea Total & 8 \\
\hline \multicolumn{2}{|c|}{ Tr } \\
\hline
\end{tabular}

Interpretation: Among 170 (61.8\%) respondents, $2.5 \%$ of the respondents felt bad, $2.9 \%$ respondents felt worst, $9.8 \%$ respondents felt tough, $38.5 \%$ of the respondents thinks that the financial crisis is manageable and $8 \%$ of the respondents have no idea

\begin{tabular}{|c|c|}
\hline Pandemic get over by & Percentage \\
\hline 2020 & 42.9 \\
\hline 2021 & 13.1 \\
\hline No idea & 44 \\
\hline Total & 100 \\
\hline
\end{tabular}

Interpretation: $42.9 \%$ of the respondents thinks this virus outbreak will get over by $2020,13.1 \%$ respondents said that it will get over by 2021 and $44 \%$ have no idea.

\begin{tabular}{|c|c|}
\hline Preferred Teaching Programmes & Percentage \\
\hline On campus & 39.6 \\
\hline Online & 14.5 \\
\hline Both & 45.5 \\
\hline Total & 100 \\
\hline
\end{tabular}

Interpretation: $39.6 \%$ respondents prefer on campus teaching, online mode of teaching is preferred by $14.5 \%$ respondents and $45.5 \%$ respondents prefer both.

\begin{tabular}{|c|c|}
\hline Change in study plan & Percentage \\
\hline Yes & 25.5 \\
\hline No & 74.5 \\
\hline Total & 100 \\
\hline
\end{tabular}

Interpretation: $25.5 \%$ of the respondents changed their study plan and $74.5 \%$ of the respondents have not changed their study plan so far.

\begin{tabular}{|c|c|}
\hline Moved lectures online & Percentage \\
\hline Yes & 89.1 \\
\hline No & 10.9 \\
\hline Total & 100 \\
\hline
\end{tabular}

Interpretation: Institutions had moved their lectures online for $89.1 \%$ of the respondents

\begin{tabular}{|c|c|}
\hline \multicolumn{1}{|c|}{ Online learning material } & Percentage \\
\hline Video conferencing \& e-material & 30.2 \\
\hline e-material \& audio lectures & 57.1 \\
\hline Audio lectures \& video conferencing & 12.7 \\
\hline Total & 100 \\
\hline
\end{tabular}

Interpretation: $30.2 \%$ respondents receive their material through video conferencing \& e-material, material provided in the form of e-material \& audiolectures for $57.1 \%$ of the respondents and audio lectures \& video conferencing is provided to $12.7 \%$ respondents.

\begin{tabular}{|l|c|}
\hline \multicolumn{1}{|c|}{ Sources used for online lectures } & Percentage \\
\hline Moodle & 1.5 \\
\hline Edx & .73 \\
\hline Google Classroom & 85.8 \\
\hline Swayam & 1.09 \\
\hline AdhaGuru & .70 \\
\hline Others Total & 10.18 \\
\hline \multicolumn{2}{|c|}{100} \\
\hline
\end{tabular}


Interpretation: The data implies that when compared to other sources Google Classrooms are widely used world over and other sources such as Zoom, Moodle, WhatsApp, SWAYAM, Webex, Meet, edX, AdhaGuru, Imartus, Udemy and Chinese app are also used to some extent for online learning.

Source: Primary Data

Table 3: Mindsets During Covid-19 Lockdown

\begin{tabular}{|l|c|c|}
\hline \multicolumn{1}{|c|}{ Traits } & Mean Score & Rank \\
\hline Fear & $2.72(748)$ & IX \\
\hline Anxiety & $2.75(756)$ & VIII \\
\hline Stress & $2.79(766)$ & VII \\
\hline Boring & $3.08(846)$ & I \\
\hline
\end{tabular}

\begin{tabular}{|l|c|c|}
\hline Dullness & $2.85(785)$ & VI \\
\hline Lazy & $2.93(807)$ & III \\
\hline Arrogant & $2.70(743)$ & X \\
\hline Anger & $2.87(790)$ & V \\
\hline Emotional at Times & $2.89(795)$ & IV \\
\hline Bursting Inside & $3(825)$ & II \\
\hline
\end{tabular}

Source: Primary Data

It is inferred that the 'boring' tops the list of mind set experienced by the students as found from its mean score of 3.08. The 'arrogant' has the least impact on respondents as found from its mean score of 2.70 .

Table 4: Spending of Time during Lock Down Period

\begin{tabular}{|l|c|c|c|}
\hline \multicolumn{1}{|c|}{ Spending of Time During Lock Down Period } & Garret score & Mean score & Rank \\
\hline Reading books & 5 & 49.19 & VI \\
\hline Watching online entertainment & 15 & 54.87 & I \\
\hline Learning online course & 25 & 52.71 & III \\
\hline Time with family & 35 & 53.61 & II \\
\hline Looking after the hobby & 45 & 50.3 & IV \\
\hline Preparing favourite dishes & 55 & 46.7 & VII \\
\hline Shooting tiktok videos & 65 & 43.06 & IX \\
\hline Involved in social activity & 75 & 39.99 & X \\
\hline College academic reports & 85 & 50.7 & V \\
\hline Future career admissions & 95 & 43.37 & VIII \\
\hline
\end{tabular}

\section{Source: Primary Data (Computed)}

With the help of Garrett ranking, it is found that watching online entertainment site is the choice of students during lock down period followed by Time with family and Learning online course is the third way of spending lock down period.
The scores of the twenty-five attributes are taken for factor analysis results in four important factors affecting the students' attitude. The four factors, the number of attributes in each factor, its reliability coefficient, Eigen value and the percent of variance are given in the below table.

Table 5: Factors Affecting the Attitude of Students Rotated Factor Matrix

\begin{tabular}{|c|l|c|c|c|c|}
\hline $\begin{array}{c}\text { S. } \\
\text { No. }\end{array}$ & \multicolumn{1}{|c|}{$\begin{array}{c}\text { Factors affecting the } \\
\text { Attitude of Students }\end{array}$} & $\begin{array}{c}\text { Number of } \\
\text { Attributes }\end{array}$ & $\begin{array}{c}\text { Eigen } \\
\text { Value }\end{array}$ & $\begin{array}{c}\text { Percent of } \\
\text { Variance }\end{array}$ & $\begin{array}{c}\text { Cumulative Percent } \\
\text { of Variance }\end{array}$ \\
\hline 1 & Future career planning & 11 & 5.956 & 19.21 & 19.21 \\
\hline 2 & Problems faced & $8(-1)$ & 3.047 & 9.82 & 29.03 \\
\hline 3 & Measures/ Remedies & $6(-1)$ & 2.011 & 6.48 & 35.52 \\
\hline 4 & Expectations & $6(-1)$ & 1.829 & 5.90 & 41.42 \\
\hline
\end{tabular}

Source: Computed data

The four factors were shown to explain the factors affecting the attitude of students to the extent of $41.42 \%$. The factors derived after the exploratory factor analysis are Future career planning, Problems faced, Measures/ Remedies and Expectations 


\section{Suggestions}

- Students in the end semester need to plan their higher education keeping the prevailing situation in the world. Parents and teachers should keep motivating them to come out of stress because of this virus outbreak.

- Various online courses are made available to all cadres of learners. This is the perfect time for the students to enhance knowledge through online learning platforms facilitated by universities/ institutions in our country and abroad. Academicians should encourage students to participate and learn in the online learning platforms for academic progression.

- This being an extraordinary pandemic situation, it is, of course a very good opportunity for the student community to adapt themselves to any kind of good and bad situations.

- Even after this pandemic gets over, it will be advisable to continue with online teaching methods as it makes the students face international challenges.

- The student community can be encouraged to undertake studies at a smaller level to understand the impact of COVID-19 on the economy. They need to survive with the skills of analyzing the situation to take corrective decisions.

\section{Conclusion}

This may be the time to reset as the destruction of the Indian and world economy is vital. It takes more than a year or two to bring back the economic enhancement in India and the responsibility to protect the vulnerable humanity from this deadly COVID-19. Indian Government, along with its citizens, have a heavy responsibility on its shoulder to revive this economy back with physical, emotional and mental ability to achieve the status of a developed nation.

\section{References}

Antushevich, Hanna. "Interplays between Inflammasomes and Viruses, Bacteria (Pathogenic and Probiotic), Yeasts and Parasites." Immunology Letters, 2020.

Burki, Talha Khan. "Coronavirus in China." The Lancet Respiratory Medicine, vol. 8, no. 3, 2020.
Gautret, Philippe, et al. "Clinical and Microbiological Effect of a Combination of Hydroxychloroquine and Azithromycin in 80 COVID-19 Patients with at least a SixDay follow up: A Pilot Observational Study." Travel Medicine and Infectious Disease, vol. 34, 2020.

Gautret, Philippe, et al. "Hydroxychloroquine and Azithromycin as a Treatment of COVID-19: Results of an Open-Label Non-Randomized Clinical Trial." International Journal of Antimicrobial Agents, vol. 56, no. 1, 2020.

Gorbalenya, Alexander E., et al. "Severe Acute Respiratory Syndrome-Related Coronavirus: The Species and its Viruses - A Statement of the Coronavirus Study Group." BioRxiv, 2020.

Hui, David S., et al. "The Continuing 2019-nCoV Epidemic Threat of Novel Coronaviruses to Global Health - The Latest 2019 Novel Coronavirus Outbreak in Wuhan, China." International Journal of Infectious Disease, vol. 91, 2020, pp. 264-266.

Kaul, Dinesh. "An Overview of Coronaviruses including the SARS-2 Coronavirus Molecular Biology, Epidemiology and Clinical Implications." Current Medicine Research and Practice, vol. 10, no. 2, 2020, pp. 54-64.

Lai, Chih-Cheng, et al. "Severe Acute Respiratory Syndrome Coronavirus 2 (SARS-CoV-2) and Coronavirus Disease-2019 (COVID-19): The Epidemic and the Challenges." International Journal of Antimicrobial Agents, vol. 55, no. 3, 2020.

Lu, Hongzhou, et al. "Outbreak of Pneumonia of Unknown Etiology in Wuhan China: the Mystery and the Miracle." Journal of Medical Virology, vol. 92, no. 4, 2020, pp. 401-402.

Molina, J.M., et al. "No Evidence of Rapid Antiviral Clearance or Clinical Benefit with the Combination of Hydroxychloroquine and Azithromycin in Patients with Severe COVID-19 Infection." Medicine et Maladies Infectieuses, vol. 50, no. 4, 2020.

Ohe, Masashi, et al. "Macrolide Treatment for COVID-19: Will this be the Way Forward?" 
Bioscience Trends, vol. 14, no. 2, 2020, pp. 159-160.

Sharifi, Ayyoob, et al. "The COVID-19 Pandemic: Impacts on Cities and Major Lessons for Urban Planning, Design, and Management." Science of the Total Environment, vol. 749, 2020.

Sheikhzadeh, Elham, et al. "Diagnostic Techniques for COVID-19 and New Developments." Talanta, vol. 220, 2020.

Tobaiqy, M., et al. "Therapeutic Management of Patients with COVID-19: A Systematic Review." Infection Prevention in Practice, vol. 2, no. 3, 2020.
en.wikipedia.org/wiki/COVID-19_pandemic_in India

https://www.ecdc.europa.eu/en/publicationsdata/download-todays-data-geographicdistribution-covid-19-cases-worldwide

https://www.mygov.in/covid-19

https://www.webmd.com/lung/coronavirus

https://www.who.int/emergencies/diseases/novelcoronavirus-2019/events-as-they-happen

mohfw.gov.in

www.cdc.gov

www.who.int/emergencies/diseases/novelcoronavirus-2019

www.who.int/india/emergencies/coronavirusdisease-(covid-19)

\section{Author Details \\ Dr. A. Margaret Divya, Assistant Professor, Department of Commerce, Lady Doak College, Madurai, Tamil Nadu, India,Email ID: mdmdivya982@gmail.com.}

Suganthi Priya, Department of Commerce, Lady Doak College, Madurai, Tamil Nadu, India,

Email ID:sp123456sss@gmail.com. 